\title{
The impact of Positive Reinforcement on Employees’ Performance in Organizations
}

\section{Leong Teen Wei, Rashad Yazdanifard}

Center for Southern New Hampshire University Programs, HELP College of Arts and Technology, Kuala Lumpur, Malaysia. Email: teenwei@gmail.com, rashadyazdanifard@yahoo.com

Received June $15^{\text {th }}, 2013$; revised July $15^{\text {th }}, 2013$; accepted July $22^{\text {nd }}, 2014$

Copyright (C) 2014 Leong Teen Wei, Rashad Yazdanifard. This is an open access article distributed under the Creative Commons Attribution License, which permits unrestricted use, distribution, and reproduction in any medium, provided the original work is properly cited. In accordance of the Creative Commons Attribution License all Copyrights (C) 2014 are reserved for SCIRP and the owner of the intellectual property Leong Teen Wei, Rashad Yazdanifard. All Copyright (C 2014 are guarded by law and by SCIRP as a guardian.

\section{ABSTRACT}

Each employee's performance is important in an organization. A way to motivate it is through the application of reinforcement theory which is developed by B. F. Skinner. One of the most commonly used methods is positive reinforcement in which one's behavior is strengthened or increased based on consequences. This paper aims to review the impact of positive reinforcement on the performances of employees in organizations. It can be applied by utilizing extrinsic reward or intrinsic reward. Extrinsic rewards include salary, bonus and fringe benefit while intrinsic rewards are praise, encouragement and empowerment. By applying positive reinforcement in these factors, desired positive behaviors are encouraged and negative behaviors are eliminated. Financial and non-financial incentives have a positive relationship with the efficiency and effectiveness of staffs.

\section{KEYWORDS}

\section{Positive Reinforcement; Employees’ Performance; Motivation}

\section{Introduction}

Over the years, managers are more concerned on employees' performances in terms of productivity and efficiency. It is very important as it affects an organization as a whole. One of the ways to provide motivation is through the application of reinforcement theory. B. F. Skinner introduced the reinforcement theory, also known as learning theory. It refers to the stimuli used to produce desired behaviors with different occurrences and schedules [1]. This paper aims to examine the productivity of employees as a result of the implementation of reinforcement theory, specifically in positive reinforcement.

\section{Positive Reinforcement}

Positive reinforcement is a technique to elicit and to strengthen new behaviors by adding rewards and incentives instead of eliminating benefits [2]. It can be applied in workplace through fringe benefit, promotion chances and pay. Rewards can be classified into two categories which are intrinsic and extrinsic. Intrinsic reward refers to something intangible such as praise and acknowledgement while extrinsic reward is salary, promotion, freedom in office and job security. Both types of rewards are closely associated with staffs' accomplishments within an organization $[3,4]$.

\section{Extrinsic Reward}

One of the basic motivations for employees to work is salary. Linz and Semykina [5] revealed that personal income is positively correlated to job satisfaction. A study of Taiwan R\&D professionals in technology sector found out that monetary incentives based on output has a positive relationship with their work performance. Besides, the monitoring cost is reduced and it became more competitive among the staffs [6]. According to Liu [7], Huawei, a Chinese information technology company offers a high basic salary and the amount is still going up every year. In comparison to other new undergraduates and graduates, Huawei pays at least RMB 4000 higher than the average rate. Huawei's reward strategy to their em- 
ployees greatly increased the organization's productivity. On the other hand, engineers in Huawei earns from \$ 6600 to \$22,000 annually, depending on their performance. The performance based technique can greatly increase the attentiveness and alertness of staffs [8].

The United States Postal Service (USPS) executed the pay-for-performance since 1995 and it made a significant impact to the organizations. The program counterbalanced the consistent net loss for the past 24 years which summed up to ten billion dollars. With the implementation of the program, the USPS not only improved drastically in financials, but in delivery punctuality, workplace safety and also efficiency [9]. When a portion of wages are reliant on performance, employees tend to work harder. However, it may lead to a vast impact to some of them because they stopped performing when pay was only reliant on their attendances in work [10].

Fringe benefit is also another instrument used in reinforcing staffs. In the year 2013, Google, Inc. ranked first in Fortune as the best company to work for. Google is well-known for its benefits for the employees. Google offers a variety of benefits such as complimentary food from cafeteria, childcare feature, healthcare, laundry services, shuttle bus, sports facilities, and a lot of holidays and even lessons for foreign languages [11]. When employees are rewarded for their performances, they will most likely to increase the behavior and perform better. Therefore, monetary or extrinsic rewards reinforced employees’ work behavior positively [12].

\section{Intrinsic Reward}

Another type of positive reinforcement is intrinsic reward. It involves something other than financial motivation. It can be mere praise, delegation, empowerment or acknowledgement, but it has an impact on employee's performance in a positive way [13,14]. When employees obtain acknowledgement from managers or supervisors as a result of their job well done, they will feel appreciated and have a sense of belonging to the company [15]. This is highly valued by staffs and it is very likely that they will strive to perform better [3].

In "The Carrot Principle" findings, it was shown that 65 percent of respondents did not receive any forms of recognition and 79 percent reported that the lack of appreciation is the main reason for quitting the organization. Those employees of highest enthusiasm, $94.4 \%$ responded that managers have recognized their competence. It showed a significant need for staffs to be recognized in order for them to be more effective in their performances. Organizations that successfully identify the brilliance have a propensity to be more lucrative and it is reported that they can gain more than three times of return [16].

More than that, Wynter-Palmer and Jennifer [17] stated that empowerment or a sense of authority given to employees is used to reinforce own capability and also enhance decision making skills at work. A study conducted in Golestan Telecommunication Company located in Iran showed that empowerment significantly improved the work performance [18]. Ritz-Carlton, a chain hotel is well-known for its gold class service. If there is a complaint or request from customer, the management allows their staffs to use up to $\$ 2000$ without manager's permission and with an approval, the amount will go higher. Ritz-Carlton demonstrated the trust and confidence to empower their staffs in order to make each of the customers satisfied [19]. In return, employees feel more satisfied with their jobs and heighten their commitment level to the company. When they give their best to the company, customers will be pleased and as a result, there will be a positive growth in revenues and profits $[20,21]$.

\section{Punishments}

Punishment is a tool used to remove unwanted or undesired actions and it can be used to decrease the intensity of behaviors [22]. Based on a study done on employees' punctuality to work, it was revealed that employees who are penalized for being late to work are effective. The percentage of employees who are late dropped $66 \%$ and $55 \%$ of them actually reported to work earlier. It demonstrated that employees who paid fines to their colleague are more successful than paying to their employer in improving their punctuality [23].

\section{Discussion}

It is found that positive reinforcement, both intrinsically and extrinsically is positively linked with the performance of employees [24]. Positive reinforcement is highly effective in strengthening and increasing behaviors. The type of reinforcement tools incorporate salary, performance-based incentives and fringe benefits. All of these encourage employees to present their best to the corporate and to sustain at the peak. Balliet, Mulder and Van Lange [25] pointed out that rewards are more effective when it is more expensive to operate. It seemed to be more valuable and more attractive, so it attains a better response. Islam and Ismail [26] pointed out the six major motivation factors for employees incorporate high salary, comfortable working condition, promotion, challenging work, job security and appreciation shown on work done. Another research provided evidences that monetary rewards offered a higher motivation to employees in comparison with non-monetary reward [27]. However, another study suggested that financial incentives will only provide a short term positive behavior. Staffs do look for more incentives which are non-monetary in order to sustain a long term positive performance in organizations [4]. Bouxsein, Roane and Harper [28] reported that the 
combination of positive reinforcement and negative reinforcement is most effective in modifying behaviors. Additionally, managers should consider different factors such race, age, gender, education level, and ethnicity when implementing these reinforcements. This is because it will help to identify which type of rewards to strengthen desired behavior. Types of rewards should be taken into account for different nature of organizations such as manufacturing, hospitality, education or retailing. These factors would help further clarify the types and intensity of reinforcement which should be used.

\section{Conclusion}

Reinforcement theory is an instrument used by managers to increase or decrease employees' behaviors. As performance and effectiveness are more emphasized nowadays, it is important to understand and utilize these concepts in motivating staffs. Positive reinforcement is seen to be the most effective way of motivating staffs to perform better in organizations. Employees are encouraged to do better as they know when each desired behavior is shown, they will be rewarded. The rewards can be intrinsic or extrinsic, or a combination of both. Rewards can be bonus based on performance, additional benefits, verbal encouragement, and empowerment. Employees feel satisfied when their work is recognized and their hard work is paid off. Punishment is another technique applied to reduce or remove certain behavior. Those who are given penalty show better discipline. However, punishment is often not favoured as it may bring down some of them. Managers should be able to decide strategically which method to use when it comes to eliciting or removing a behavior. A consequence-based technique is very effective in managing an individual or even a team of staffs.

\section{REFERENCES}

[1] B. F. Skinner, “Operant Behaviour,” American Psychologist, Vol. 18, No. 8, 1963, pp. 503-515. http://dx.doi.org/10.1037/h0045185

[2] A. Catania, "Positive Psychology and Positive Reinforcement,” American Psychologist, Vol. 56, No. 1, 2001, pp. 86-87. http://dx.doi.org/10.1037/0003-066X.56.1.86

[3] P. Gohari, A. Ahmadloo, M. B. Boroujeni and S. J. Hosseinipour, "The Relationship between Rewards and Employee Performance," Interdisciplinary Journal of Contemporary Research in Business, Vol. 5, No. 3, 2013, pp. 543-570.

[4] R. M. Zani, N. A. Rahim, S. Junos, S. Samanol and S. S. Ahmad, "Comparing the Impact of Financial and NonFinancial Rewards towards Organizational Motivation," Interdisciplinary Journal of Contemporary Research in Business, Vol. 3, No. 4, 2011, pp. 328-334.

[5] S. J. Linz and A. Semykina, "What Makes Workers
Happy? Anticipated Rewards and Job Satisfaction,” Industrial Relations, Vol. 51, No. 4, 2012, pp. 811-844. http://dx.doi.org/10.1111/j.1468-232X.2012.00702.x

[6] M. S. Chien, J. S. Lawler and U. Jin-Feng, "Performance-Based Pay, Procedural Justice and Job Performance for R\&D Professionals: Evidence from the Taiwanese High-Tech Sector," International Journal of Human Resource Management, Vol. 21, No. 12, 2010, pp. 22342248.

[7] Y. Liu, "Reward Strategy in Chinese IT Industry," International Journal of Business and Management, Vol. 5, No. 2, 2010, pp. 119-127.

[8] R. Hübner and J. Schlösser, "Monetary Reward Increases Attentional Effort in the Flanker Task," Psychonomic Bulletin \& Review, Vol. 17, No. 6, 2010, pp. 821-826.

[9] J. Schuster, P. Weatherhead and P. Zingheim, "Pay for Performance Works: The United States Postal Service Presents a Powerful Business Case,” Worldat Work Journal, Vol. 15, No. 1, 2006, pp. 24-31.

[10] M. N. Koffarnus, A. DeFulio, S. O. Sigurdsson and K. Silverman, "Performance Pay Improves Engagement, Progress, and Satisfaction in Computer-Based Job Skills Training of Low-Income Adults," Journal of Applied Behavior Analysis, Vol. 46, No. 2, 2013, pp. 395-406. http://dx.doi.org/10.1002/jaba.51

[11] R. Kuntze and E. Matulich, "Google: Searching for Value," Journal of Case Research in Business and Economics, Vol. 2, 2010, pp. 1-10.

[12] A. Rudge, "Birmingham City Council Links Increased Contribution and Outcomes to Reward and Recognition,” Human Resource Management International Digest, Vol. 19, No. 5, 2011, pp. 6-8.

[13] P. Sonawane, "Non-monetary Rewards: Employee Choices \& Organizational Practices," Indian Journal of Industrial Relations, Vol. 44, No. 2, 2008, pp. 256-271.

[14] J. L. Howard, "The Use of Non-Monetary Motivators in Small Business,” The Entrepreneurial Executive, Vol. 13, 2008, pp. 17-29.

[15] N. Shiraz, M. Rashid and A. Riaz, "The Impact of Reward and Recognition Programs on Employee's Motivation and Satisfaction," Interdisciplinary Journal of Contemporary Research in Business, Vol. 3, No. 3, 2011, pp. 1428-1434.

[16] American Optometric Association, "Staff Recognition," Optometry-Journal of the American Optometric Association, Vol. 82, No. 9, 2011, pp. 566-567.

[17] J. E. Wynter-Palmer, "Is the Use of Short-Term Incentives Good Organization Strategy?” Compensation \& Benefits Review, Vol. 44, No. 5, 2012, pp. 254-265.

[18] S. Siami, and M. Gorji, “Assessment of Effect of Empowerment on Employees Performance (Case study Telecommunication Company)," Business \& Management Review, Vol. 1, No. 8, 2011, pp. 20-24.

[19] “Ritz-Carlton Employees Go for Gold,” In: Human Resource Management International Digest, Vol. 10, No. 7, 2002, pp. 23-25.

[20] A. Sarwar and A. Khalid, "Impact of Employee Empowerment on Employee's Job Satisfaction and Commitment 
with the Organization,” Interdisciplinary Journal of Contemporary Research in Business, Vol. 3, No. 2, 2011, pp. 664-683.

[21] D. Elloy, “Effects of Ability Utilization, Job Influence and Organization Commitment on Employee Empowerment: An Empirical Study," International Journal of Management, Vol. 29, No. 2, 2012, pp. 627-632.

[22] P. S. Hall, “A New Definition of Punishment,” Reclaiming Children and Youth, Vol. 21, No. 4, 2013, pp. 22-26.

[23] C. K. Siang, "Punishment as a Price to Pay," Contemporary Economics, Vol. 6, No. 1, 2012, p. 86.

[24] S. J. Peterson and F. Luthans, "The Impact of Financial and Nonfinancial Incentives on Business-Unit Outcomes over Time,” Journal of Applied Psychology, Vol. 91, No. 1, 2006, pp. 156-165. http://dx.doi.org/10.1037/0021-9010.91.1.156

[25] D. Balliet, L. B. Mulder and P. M. Van Lange, "Reward,
Punishment, and Cooperation: A Meta-Analysis," Psychological Bulletin, Vol. 137, No. 4, 2011, pp. 594-615. http://dx.doi.org/10.1037/a0023489

[26] R. Islam and A. Z. H. Ismail, "Employee Motivation: A Malaysian Perspective," International Journal of Commerce \& Management, Vol. 18, No. 4, 2008, pp. 344-362. http://dx.doi.org/10.1108/10569210810921960

[27] F. B. Zaidi and Z. Abbas, "A Study on the Impact of Rewards on Employee Motivation in the Telecommunication Sector of Pakistan," Interdisciplinary Journal of Contemporary Research in Business, Vol. 3, No. 3, 2011, pp. 978-998.

[28] K. J. Bouxsein, H. S. Roane and T. Harper, "Evaluating the Separate and Combined Effects of Positive and Negative Reinforcement on Task Compliance,” Journal of Applied Behavior Analysis, Vol. 44, No. 1, 2011, pp. 175179. 